\title{
Standardization of SYBR Green Based Real Time PCR for Detection of Canine Parvovirus-2 (CPV-2)
}

\author{
Srinivas Manchikatla ${ }^{1^{*}}$, Narasimha Reddy Yella ${ }^{1}$ and Kalyani Putty ${ }^{2}$ \\ ${ }^{1}$ Department of Veterinary Microbiology, ${ }^{2}$ Department of Veterinary Biotechnology, College \\ of Veterinary Science, Rajendranagar, Hyderabad-500030, India \\ *Corresponding author
}

Keywords

Real time PCR, Canine parvovirus, Conventional PCR, SYBR green dye, Phenol chloroform method, DNA extraction

\section{Article Info}

Accepted:

28 August 2020

Available Online:

10 September 2020

\section{A B S T R A C T}

CPV-2 infection in dogs is recognized as one of the most common diseases especially in young puppies of less than a year age. Keeping in view of frequency of the occurrence of infection, sometimes even in vaccinated animals, the present study was taken up with the objective of standardizing the Real time PCR for easy and rapid diagnosis of the CPV-2 virus. In the present investigation a total of 100 faecal samples/rectal swabs were collected from dogs suffering with gastrointestinal disorders and showing the symptoms of canine parvovirus, like bloody diarrhoea, vomiting and pyrexia. The samples were tested initially with SYBR green dye based real time PCR with different combinations of the cycles and the results obtained were further confirmed by conventional PCR. We could able to standardize the real time PCR which was more helpful in screening of the faecal samples further in large numbers.

\section{Introduction}

Gastroenteritis, resulting in vomiting and diarrhea is one of the major diseases commonly encountered in dogs. This can occur quite quickly, be very dangerous to the pet's health and, if left untreated, leads to death - especially in young animals. Various causative agents of canine viral enteritis include canine parvovirus (CPV), canine distemper virus, canine adenovirus-1, canine coronavirus, canine rotavirus etc. (Decaro et al., 2007a).

One of the most devastating viral diseases of canine population is CPV enteritis which is highly contagious worldwide and is still evolving (Shackelton et al., 2005). Since the initial parvovirus enteritis pandemic following the emergence of CPV type 2 
(CPV-2), three variants, namely CPV-2a, CPV-2b and CPV-2c completely replaced the original type-2 viruses (Buonavoglia et al., 2001; Filipov et al., 2011). Canine parvovirus infection is a serious threat to canine population and has been reported from many parts of the world (Carmichael, 2005). This infection is an emerging disease in India and the incidence is showing an increasing trend (Chinchkar et al., 2006; Sanjukta et al., 2011; Wazir et al., 2011). Clinical diagnosis of CPV infection is difficult, because the main clinical sign of the disease are common to other enteric diseases as well (Castro et al., 2011). However, polymerase chain reaction (PCR) technique has been widely applied for early and confirmatory laboratory diagnosis of the disease due to high sensitivity and specificity (Nandi et al., 2010a). But the advanced Real time PCR is more sensitive and less time consuming than the conventional PCR. Keeping in view of this we have standardized the Real time PCR in our laboratory for rapid diagnosis of the CPV-2 virus.

\section{Materials and Methods}

\section{Collection and processing of samples}

A total of 100 faecal samples/rectal swabs were collected from dogs exhibiting clinical signs viz., gastroenteritis, haemorrhagic enteritis, pyrexia etc. from teaching Veterinary Hospital, College of Veterinary Science, Rajendranagar, Hyderabad and various Private clinics in Hyderabad. These faecal samples were used in the present study. The faecal samples/rectal swabs obtained from the suspected dogs were emulsified in 1 $\mathrm{mL}$ of 0.1 M PBS (pH 7.4) containing antibiotics (100 IU/mL Benzyl Penicillin, 100 $\mu \mathrm{g} / \mathrm{mL}$ Streptomycin sulphate) centrifuged at $6000 \mathrm{rpm}$ for $10 \mathrm{~min}$ at $4^{0} \mathrm{C}$. The supernatant was collected and filtered through $0.22 \mu$ syringe filter and stored at $-20^{\circ} \mathrm{C}$ until further use.

\section{Extraction of DNA}

The following 2 different procedures was followed and standardized according to the convenience and ease of doing, initially the standard phenol chloroform extraction method was followed as given below

One $\mathrm{ml}$ of the fecal sample was spun in a microcentrifuge for $2 \mathrm{~min}$, or until a compact pellet was formed. The supernatant was discarded and the pellet was resuspended in $567 \mu 1 \mathrm{TE}$ buffer by repeated pipetting. Then $30 \mu \mathrm{l}$ of $10 \%$ SDS and $3 \mu \mathrm{l}$ of $20 \mathrm{mg} / \mathrm{ml}$ proteinase $\mathrm{K}$ were added to give a final concentration of $100 \mu \mathrm{g} / \mathrm{ml}$ proteinase $\mathrm{K}$ in $0.5 \%$ SDS. Mixed thoroughly and incubated 1 $\mathrm{hr}$ at $37^{\circ} \mathrm{C}$. The solution become viscous as the detergent lyses the bacterial cell walls. Then add $100 \mu \mathrm{l}$ of $5 \mathrm{M} \mathrm{NaCl}$, mix thoroughly and add $80 \mu \mathrm{l}$ of $\mathrm{CTAB} / \mathrm{NaCl}$ solution and mix thoroughly and incubate 10 $\min$ at $65^{\circ} \mathrm{C}$.

Add an approximately equal volume (0.7 to $0.8 \mathrm{ml}$ ) of chloroform/isoamyl alcohol (24:1) mix thoroughly, and spin 4 to $5 \mathrm{~min}$ in a microcentrifuge. This extraction removes CTAB-protein/polysaccharide complexes. A white interface will be visible after centrifugation.

Remove aqueous, viscous supernatant to a fresh microcentrifuge tube, leaving the interface behind. Add an equal volume of phenol/chloroform/isoamyl alcohol (25:24:1), mix thoroughly, and spin in a microcentrifuge for $5 \mathrm{~min}$.

Transfer the supernatant to a fresh tube. Add 0.6 vol isopropanol to precipitate the nucleic acids. Shake the tube back and forth until a stringy white DNA precipitate becomes clearly visible. The precipitate can be pelleted by spinning briefly at room temperature. If no stringy DNA precipitate forms in the above 
step, this implies that the DNA has sheared into relatively low-molecular-weight pieces.

Wash the DNA with $70 \%$ ethanol to remove residual $\mathrm{CTAB}$ and respin for $5 \mathrm{~min}$ at room temperature to repellet it. Carefully remove the supernatant and briefly dry the pellet. Redissolve the pellet in $100 \mu \mathrm{l}$ TE buffer.

The second protocol followed was detailed below (Decaro et al., 2007b)

$100 \mu \mathrm{L}$ of faecal sample was used for template DNA preparation.

The samples were boiled at $96^{\circ} \mathrm{C}$ for $10 \mathrm{~min}$ and immediately chilled in crushed ice.

The samples were then centrifuged at 12,000 rpm for $10 \mathrm{~min}$ at $4^{0} \mathrm{C}$ using cooling centrifuge (Centrifuge 5810 R, Eppendorf).

The supernatant was then diluted 1:5 in nuclease free water to reduce residual inhibitors of DNA polymerese activity and used as template for PCR.

\section{Positive control}

Commercially available live attenuated vaccine for CPV-2 (Canigen DHPPi) served as positive control. The vaccine DNA was extracted using the same procedures mentioned above.

\section{Real-time PCR}

Real-time PCR was carried out using SYBR ${ }^{\circledR}$ Premix Ex Taq $^{\mathrm{TM}}$ PCR Master Mix (Cat.No.RR420A; TaKaRa) with CPV-2 primer set (Table 1), in StepOnePlus Realtime PCR system (instrument) from Applied Biosystems (Kumar M and Nandi S 2010). Primers were reconstituted with nuclease free water to obtain $100 \mathrm{pmol} / \mu \mathrm{L}$ stocks. Stocks were made into $10 \mathrm{pmol} / \mu \mathrm{L}$ working solution and used for PCR. Real-time PCR was standardized for the primer set of CPV-2 as reported by Decaro et al., (2007b)

SYBR $^{\circledR}$ Premix Ex Taq ${ }^{\mathrm{TM}}$ PCR Master Mix (2X concentration) contains $\mathrm{SYBR}^{\circledR}$ Green I Dye, AmpliTaq Gold $^{\circledR}$ DNA polymerase, dNTPs, Passive reference and Optimized buffer components. The SYBR Green dye binds to DNA, thus providing a fluorescent signal that reflects the amount of ds DNA product generated during PCR.

The SYBR ${ }^{\circledR}$ Premix Ex Taq ${ }^{\mathrm{TM}}$ PCR Master Mix and the working solution of primer set were allowed to thaw completely. Then were mixed gently and spun briefly.

PCR master mix was prepared by scaling the volumes listed below to the desired number of PCR reactions.

\begin{tabular}{|c|c|}
\hline Reaction Component & Volume \\
\hline Power SYBR $^{\circledR} \quad$ Green & $5 \mu \mathrm{L}$ \\
\hline PCR Master Mix (2X) & \\
\hline Forward primer $(10 \mu \mathrm{M})$ & $0.5 \mu \mathrm{L}$ \\
\hline Reverse primer $(10 \mu \mathrm{M})$ & $0.5 \mu \mathrm{L}$ \\
\hline Template DNA & $1 \mu \mathrm{L}$ \\
\hline ROX dye & $1 \mu \mathrm{L}$ \\
\hline Nuclease-free water & $2 \mu \mathrm{L}$ \\
\hline Total & $10 \mu \mathrm{L}$ \\
\hline
\end{tabular}

The PCR mixture was mixed gently and spun briefly.

Then PCR reaction plate was prepared by distributing $9 \mu \mathrm{L}$ of PCR mixture into each well of MicroAmp ${ }^{\circledR}$ Fast 96-Well Reaction Plate, to that $1 \mu \mathrm{L}$ of template DNA was added, according to template sheet including No Template Control and Positive Template Control.

The Multiwell Plate was transferred into the plate holder of the StepOnePlus Realtime PCR system Thermal Cycling block. Then the programmed platedocument was run according to following cycling conditions for 
amplification and melt curve generation.

\section{Reaction conditions of real time PCR}

To standardize the reaction conditions for the CPV-2 primer set, we have tried with 3 different combinations of denaturation, annealing and extension and the reaction conditions are listed in the tables $(2,3 \& 4)$.

\section{Results and Discussion}

In order to test more number of samples for canine parvovirus and other enteric viral diseases, we have standardized the Real time PCR in place of conventional PCR in order to save time and laborious process of agarose gel preparation and viewing under the UV transilluminator.

Initially we have screened 100 DNA samples by Real-time PCR (Fig.I \& II) using CPV-2 primers and 43 samples tested positive. The positive samples were further confirmed by conventional PCR (data not shown) using CPV-2ab primers and almost same number of samples (a few lesser) were tested positive in conventional PCR suggesting the high sensitivity of the Real time PCR (Kaur et al., 2016). For DNA extraction first we have followed the standard phenol chloroform method and since it is time consuming and laborious process we shifted to boiling method to extract DNA as suggested by Deacaro et al., and the results when compared to the standard phenol chloroform method was identical and hence we have shifted to the physical method of DNA extraction to all our samples. To optimize the reaction conditions for the given primer set, we have done 3 different combinations of the temperatures for denaturation, Annealing and extension. Finally we have arrived at the conclusion, that the $3^{\text {rd }}$ set of combination trial was good in amplifying our products when compared to the previous 2 trials.

In the first two trials the amplification curves were abnormal and the positive control whose $\mathrm{Ct}$ value was expected to be lower than the samples was a bit higher or equal or sometimes not even amplified. While in the third trial the amplification of the positive control was consistently good and the $\mathrm{Ct}$ value was lower than that of the samples.

Table.1 Real time PCR primers used for CPV-2 detection

\begin{tabular}{|l|l|c|}
\hline $\begin{array}{l}\text { Forward and } \\
\text { reverse primers }\end{array}$ & Primer Sequence (5'-3') direction & $\begin{array}{c}\text { Tm value and } \\
\text { fragment size }\end{array}$ \\
\hline $\begin{array}{l}\text { CPV-2 (F) } \\
\text { CPV-2 (R) }\end{array}$ & AAACAGGAATTAACTATACTAATATATTT & $60^{\circ} \mathrm{c}$ \\
\hline
\end{tabular}

Table.2 Reaction conditions of real time PCR for detection of CPV-2 (trial 1)

\begin{tabular}{|c|c|c|c|c|c|}
\hline Enzyme & & PCR & \multicolumn{3}{|c|}{ Melt Curve Stage } \\
\hline \multirow[b]{2}{*}{ Hold } & \multicolumn{2}{|c|}{ Cycles (45 cycles) } & & & \\
\hline & Denaturation & Annealing/Extension & & & \\
\hline $10 \mathrm{~min}$ & $15 \mathrm{sec}$ & $1 \mathrm{~min}$ & $15 \mathrm{sec}$ & $1 \mathrm{~min}$ & $15 \mathrm{sec}$ \\
\hline $95^{\circ} \mathrm{C}$ & $95^{\circ} \mathrm{C}$ & $60^{\circ} \mathrm{C}$ & $95^{\circ} \mathrm{C}$ & $60^{\circ} \mathrm{C}$ & $95^{\circ} \mathrm{C}$ \\
\hline
\end{tabular}


Table.3 Reaction conditions of real time PCR for detection of CPV-2 (trial 2)

\begin{tabular}{|c|c|c|c|c|c|}
\hline $\begin{array}{c}\text { Enzyme } \\
\text { Activation }\end{array}$ & & PCR & \multirow{3}{*}{\multicolumn{3}{|c|}{ Melt Curve Stage }} \\
\hline \multirow[b]{2}{*}{ Hold } & \multicolumn{2}{|c|}{ Cycles (40 cycles) } & & & \\
\hline & Denaturation & Annealing/Extension & & & \\
\hline $2 \mathrm{~min}$ & $15 \mathrm{sec}$ & $2 \min$ & $15 \mathrm{sec}$ & $1 \mathrm{~min}$ & $15 \mathrm{sec}$ \\
\hline $95^{\circ} \mathrm{C}$ & $95^{\circ} \mathrm{C}$ & $60^{\circ} \mathrm{C}$ & $95^{0} \mathrm{C}$ & $60^{\circ} \mathrm{C}$ & $95^{\circ} \mathrm{C}$ \\
\hline
\end{tabular}

Table.4 Reaction conditions of real time PCR for detection of CPV-2 (trial 3)

\begin{tabular}{|c|c|c|c|c|c|}
\hline $\begin{array}{l}\text { Enzyme } \\
\text { Activation }\end{array}$ & \multicolumn{3}{|c|}{ PCR } & \multirow{2}{*}{\multicolumn{2}{|c|}{ Melt Curve Stage }} \\
\hline \multirow{2}{*}{ Hold } & \multicolumn{3}{|c|}{ Cycles (40 cycles) } & & \\
\hline & Denaturation & Annealing & Extension & & \\
\hline $30 \mathrm{sec}$ & $05 \mathrm{sec}$ & $1 \mathrm{~min}$ & $1 \mathrm{~min}$ & $15 \mathrm{sec}$ & $1 \mathrm{~min}$ \\
\hline $95^{\circ} \mathrm{C}$ & $95^{\circ} \mathrm{C}$ & $48^{0} \mathrm{C}$ & $60^{\circ} \mathrm{C}$ & $95^{\circ} \mathrm{C}$ & $60^{\circ} \mathrm{C}$ \\
\hline
\end{tabular}

Fig.I Amplification plot of Real-time PCR of suspected faecal samples with CPV-2 primers

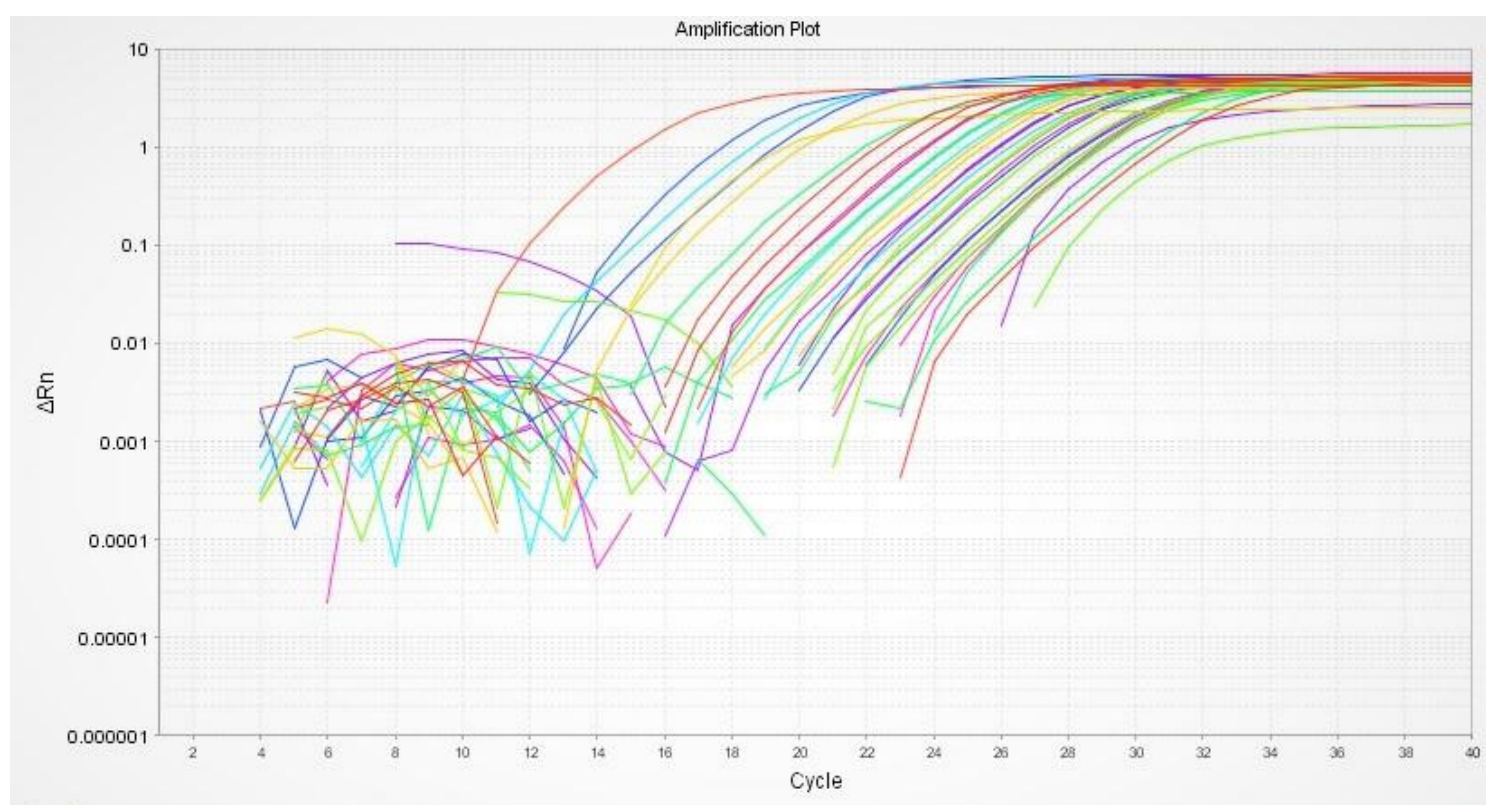

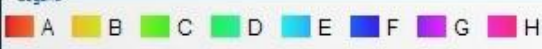

Amplification curve showing CT values of positive control (first curve to the left), CPV-2 isolates and negative control (undetermined) as template using CPV-2 primers and SYBR green dye based detection. 
Fig.2 Melt curve obtained in SYBR green dye based Real-time PCR using CPV-2 primers

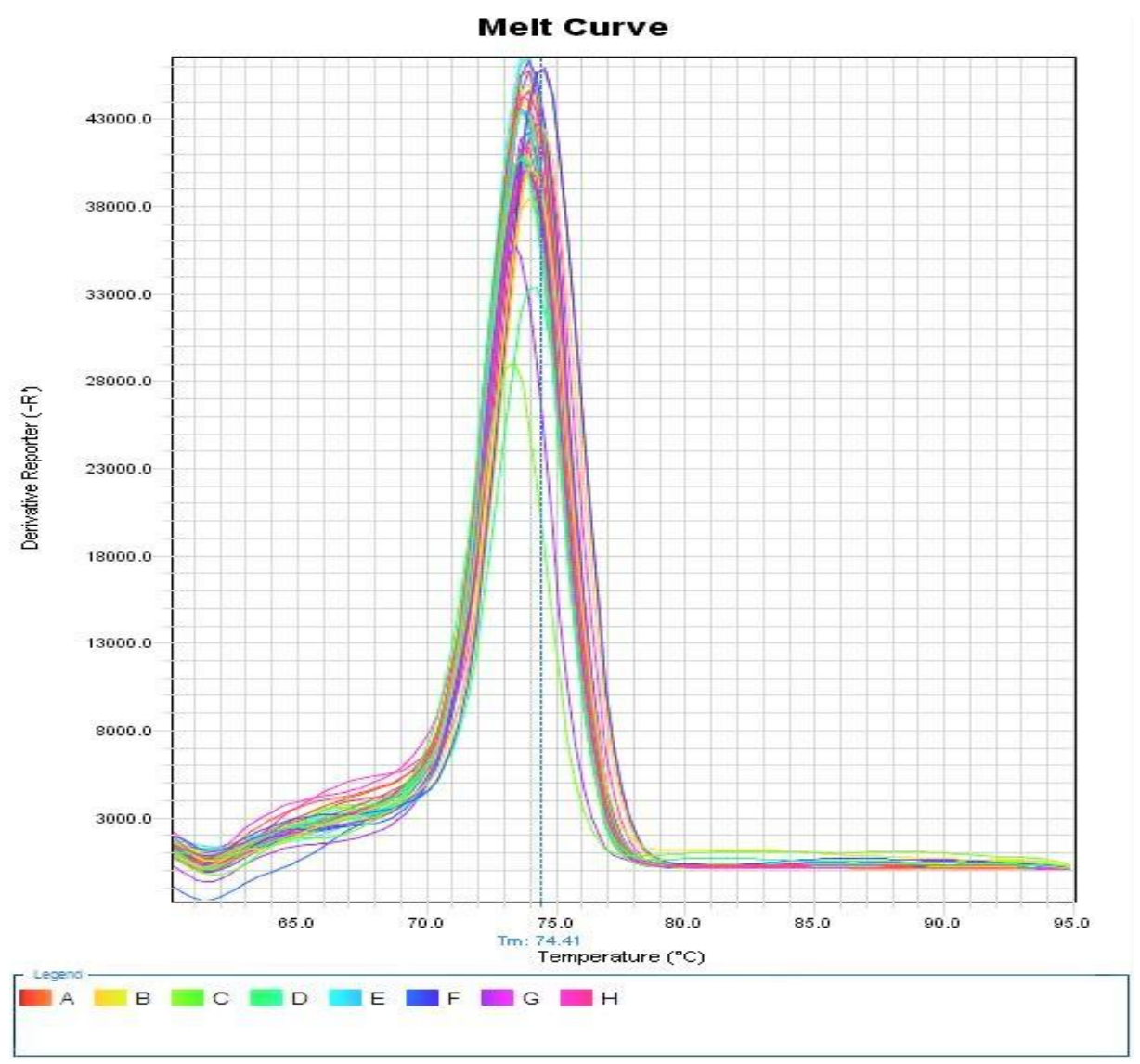

Melt curve showing Tm values of positive control, CPV-2 isolates and negative control (undetermined) in SYBR green dye based detection of the amplicon in CPV-2 specific Real-time PCR suggesting the specificity of the reaction with no primer dimers.

Once we have standardized the real time PCR for CPV-2, we have further screened more than 400 samples in our laboratory and were much easier and less laborious than conventional PCR which was followed earlier.

In conclusion the Real time PCR for screening of fecal samples for CPV-2 was standardized and was even more convenient than conventional PCR and can be replaced with suitable equipment.

\section{Acknowledgements}

I am highly thankful to the principal investigator, project on viral agents involved in canine gastroenteritis sponsored by Department of Biotechnology, Ministry of Science \& Technology, Govt. of India.

\section{References}

Buonavoglia C., Martella V., Pratelli A., Tempesta M., Cavalli A., Buonavoglia D. and Carmichael L. 2001. Evidence for evolution of canine parvovirus type 2 in Italy. Journal of General Virology. 82: 3021-3025.

Carmichael L E. An annotated historical account of canine parvovirus. 2005. J. Vet. Med. B. Infect. Dis. Vet. Public. Health. 52: 303-311.

Castro T X, Costa E M, Leite J P, Labarthe N 
V and Garcia R C. 2011. Monitoring of canine parvovirus (CPV) strains detected in vaccinated puppies in Brazil. Research in veterinary science 90: 336340.

Chinchkar S R, Subramanian B M, Rao N H, Rangarajan P N, Thiagarajan D and Srinivasan V A. 2006. Analysis of VP2 gene sequences of canine parvovirus isolates in India. Archives of virology. 151: 1881-1887.

Decaro N, Desario C, Addie D D, Martella V, Vieira M J, Elia $G$ and Truyen U. 2007a. Molecular epidemiology of canine parvovirus, Europe. Emerging infectious diseases 13: 1222.

Decaro N, Martella V, Elia G, Desario C, Campolo M, Lorusso $\mathrm{E}$ and Buonavoglia C. 2007b. Tissue distribution of the antigenic variants of canine parvovirus type 2 in dogs. Veterinary Microbiology. 121: 39-44.

Filipov C, Decaro N, Desario C, Amorisco F, Sciarretta R, Buonavoglia C. 2011. Canine parvovirus epidemiology in Bulgaria. J. Vet. Diagn. Invest., 23: $152-154$.

Kaur G, Chandra M, Dwivedi $\mathrm{P} N$ and Narang D. 2016. Multiplex real-time PCR for identification of canine parvovirus antigenic types. Journal of virological methods. 233: 1-5.
Kumar M and Nandi S. 2010. Development of a SYBR Green based real-time PCR assay for detection and quantitation of canine parvovirus in faecal samples. Journal of virological methods. 169: 198-201.

Nandi S, Chidri S, Kumar M and Chauhan R S. 2010. Occurrence of canine parvovirus type $2 \mathrm{c}$ in the dogs with haemorrhagic enteritis in India. Research in veterinary science. 88: 169171.

Sanjukta R, Kumar M and Mandakini R. 2011. Epidemiological study of canine parvovirus. Indian Vet. J. 88(12):77-79.

Shackleton LA, Parrish CR, Truyen U, and Holmes EC. 2005. High rate of viral evolution associated with the emergence of carnivore parvovirus. Proc Natl Acad Sci USA 102: 379-384

Wazir VS, SK Gupta, RK Bhardwaj, AK Taku, JS Soodan, SK Kotwal, R Singh and VP Singh. 2011. Clinic hematological alterations in CPV gastroenteritis in canines. Proceedings of $29^{\text {th }}$ ISVM Convention and National Symposium on "Recent Developments in Diagnostics and Therapeutics Including Applications of NanoTechnology in Veterinary Medicine". $17^{\text {th }}-19^{\text {th }}$ February 2011.

\section{How to cite this article:}

Srinivas Manchikatla1, Narasimha Reddy Yella1 and Kalyani Putty. 2020. Standardization of SYBR Green Based Real Time PCR for Detection of Canine Parvovirus-2 (CPV-2). Int.J.Curr.Microbiol.App.Sci. 9(09): 3716-3722. doi: https://doi.org/10.20546/ijcmas.2020.909.458 